FRIEDRICH ENGELS 200 ANOS

\title{
FRIEDRICH ENGELS 200 ANOS
}

FRIEDRICH ENGELS 200 ANOS

DOI: http://dx.doi.org/10.9771/gmed.v12i3.43141

\author{
Muniz Ferreira ${ }^{1}$
}

Este Volume 12, N. 3 conversa sobre as contribuições de Friedrich Engels com o Professor Muniz Ferreira. O Roteiro, elaborado por Maria de Fátima Rodrigues Pereira, Pedro Leão da Costa Neto e Rodrigo Castelo explora a trajetória de estudos do entrevistado acerca da abordagem das relações internacionais em perspectiva marxista, do próprio marxismo e da obra de Marx e Engels. O resultado é uma interessante reflexão que recupera a própria trajetória intelectual de Muniz Ferreira, destacando-se aqui os estudos sobre a abordagem de Marx e Engels sobre as relações internacionais, sem perder de vista a análise da relevância das contribuições de Engels para o marxismo. Boa leitura!!

Germinal: Professor Muniz, você poderia falar sobre a sua formação intelectual e como se deu a sua aproximação com o marxismo e o comunismo e seu interesse no estudo de Engels?

Cabe, inicialmente, uma apresentação formal. Meu nome é Muniz Gonçalves Ferreira, nasci na cidade do Rio de Janeiro em 02/02/1964. Sou professor de História Contemporânea, lotado no Departamento de História da Universidade Federal Rural do Rio de Janeiro (UFRRJ), função que desempenho desde junho de 2012. Antes disto, exerci a docência por um período de 15 anos (1997-2012) na Graduação e no Programa de Pós-Graduação em História da Universidade Federal da Bahia.

A opção por um curso na área de ciências humanas decorreu, mais ou menos coerentemente, da minha aspiração de obter uma compreensão qualificada dos mecanismos e processos de uma realidade política econômica e social com a qual minha consciência se encontrava em aberto dissídio desde os primórdios da adolescência. Dissensão em grande medida alimentada por minha origem em uma família negra e proletária, bem como em minha entrada precoce no mercado de trabalho. Além disto, experimentara o desabrochar de um raciocínio crítico alicerçado em leituras e na observação da dinâmica dos acontecimentos histórico políticos da segunda metade dos anos 1970, caracterizados pela agudização da crise de legitimação da ditadura militar, então ainda em vigor no país, da intensificação e aprofundamento 
da movimentação das forças políticas e sociais do campo oposicionista e da reanimação dos movimentos operário e popular.

Ao ingressar na graduação em História, já me considerava portador de uma opção política, uma concepção de mundo e um método de interpretação da realidade histórico social. No desenrolar do curso, estes elementos foram postos à prova, estimulando revisões, aperfeiçoamentos e confirmações. A universidade, talvez mais que outros ambientes da sociedade, repercutia intensamente os embates, as definições e os dilemas vivenciados pela sociedade brasileira naqueles anos de ampliação da abertura política, declínio sistemático do regime militar e ingresso do país no processo de transição à institucionalidade liberal representativa. Espaço por excelência da reflexão, do debate e da produção do conhecimento, praticamente todas as visões da realidade, projetos, propostas e posicionamentos políticos encontravam-se representados ali. Boa parte dos integrantes dos três setores constitutivos da comunidade universitária (servidores, professores e estudantes), se já não chegavam conscientizados e politizados na universidade, encontravam nela ambiente plenamente favorável para seu engajamento e politização.

A tradição marxista, minha bússola teórica e metodológica, era uma das referências historiográficas estudadas e debatidas no curso. Os movimentos operário e comunista eram tematizados e estudados, ainda que sem muita profundidade, em algumas disciplinas. A história política brasileira e internacional constituíam objetos frequentes de investigação, reflexão e debate. Tão marcante era a interseção entre nossos temas de estudos e pesquisas e os interesses e preocupações concernentes à militância política que uma atividade parecia desdobrar-se da outra.

Fui afortunado em encontrar no curso, e mesmo nas turmas que frequentei, estudantes que compartilhavam deste entendimento. Isto, apesar das eventuais divergências políticas e programáticas, nos aproximou tanto no empenho acadêmico quanto no ativismo estudantil. Aplicávamo-nos ao estudo para não só adquirir uma boa formação, mas também sustentar satisfatoriamente a argumentação nos debates e discussões onde se problematizavam e/ou criticavam nossas referências teóricas e afiliações políticas (o marxismo, nossos partidos políticos, os estados e regimes que pretendíamos apoiar).

Concluí a Licenciatura em História em 1987. Em 1988 Ingressei no Mestrado em Relações Internacionais, uma experiência muito diferente em mais de um aspecto daquilo que vivi anteriormente. Até aqui, toda a minha formação escolar e acadêmica fora em instituições de ensino públicas e gratuitas e de repente estava integrado ao corpo discente da mais cara e elitizada universidade do estado do Rio de Janeiro. Se o caráter público e gratuito da UFF contribuiu para que grande parte de meus colegas fosse, assim como eu, filha da classe trabalhadora - formada por indivíduos provenientes da zona norte e do subúrbio, alguns ainda conciliando o exercício profissional com o estudo universitário, na PUC me vi inserido em um meio bastante diverso. De Niterói, cidade situada na região metropolitana do Rio de Janeiro, para muitos uma autêntica periferia da capital fluminense, fui deslocado para o epicentro da zona urbana mais valorizada da cidade: a Gávea (Zona Sul), antigo bairro operário convertido em estrondoso exemplo de "higienização social" e gentrificação, que possuía em seu território o "Baixo Gávea", espaço de badalação e vivência boêmia da jeunesse dorée... 
Os demais alunos de minha turma eram, quase sem exceção, oriundos de famílias abastadas da sociedade carioca e outras. Diplomatas e filhos de diplomatas, industriais e filhos de industriais, praticamente todos com fluência em idiomas estrangeiros adquirida através de extensas permanências no exterior, quando não do próprio nascimento fora do país. A diferença na extração de classe também se refletia nas escolhas e simpatias políticas. Se na "Fluminense" me via rodeado por anarquistas, trotsquistas, prestistas, brizolistas, católicos de esquerda, seguidores de Enver Hodja, ecologistas e pós-modernos, onde constantemente me situava mais "à direita”, na PUC, meu "comunismo marxista” me fez objeto de complacente curiosidade da parte de colegas liberais, sociais-democratas da "terceira via", socialistas moderados e escassos integrantes da então "direita" light do PT. Entre os professores, a situação era ainda mais diversa. Se na graduação em História o distanciamento em face do marxismo e do movimento comunista era assumido por docentes, que, assim como os estudantes, aderiam majoritariamente a outros posicionamentos teóricos e políticos também situados à esquerda, no mestrado do IRI tive como preletores economistas neoclássicos, sociólogos funcionalistas, politólogos adeptos da teoria dos jogos e analistas internacionais de formação conservadora e liberal.

Lembremos que aqueles anos (1988-1991) se caracterizaram pela crise, colapso geral e encerramento das experiências de transição socialista nos países da Europa Centro Oriental. Concomitantemente, o credo neoliberal se afirmava e disseminava vitoriosamente ao redor do mundo, gerando uma nova sucessão de declarações de morte, obituários e epitáfios da tradição marxista, do movimento operário, da revolução e do comunismo...

Com o colapso do chamado "socialismo real", ou "socialismo realmente existente" (sorex) e a ascensão das concepções neoliberais, o centro das discussões internacionais se deslocava gradativamente da abordagem das questões políticas e ideológicas características da guerra fria para a dimensão econômica, na qual se destacava o tema da globalização. No âmbito desta tematização, o problema da corrosão lenta, porém sistemática, da centralidade econômica internacional dos Estados Unidos e a ascensão de "novos" potenciais protagonistas econômicos, como Alemanha/União Europeia e Japão, conquistava grande relevância. Em minhas leituras sobre a situação da economia internacional na época, o Japão era frequentemente caracterizado como uma potência econômica em ascensão, que desafiava a hegemonia estadunidense e caminhava para se converter na principal economia do mundo... Indagando sobre o status das relações econômicas entre o Brasil e o Japão, o desenvolvimento, no curso da história, deste relacionamento e as implicações, para o Brasil, da cristalização de um eventual protagonismo japonês na economia mundial elaborei o projeto de pesquisa que resultou na dissertação intitulada Investimentos diretos japoneses na indústria brasileira (1951-1985), defendida no IRI-PUC, em 29/04/1992.

O desafio apresentado a quem se mantinha no âmbito da tradição marxista e da militância socialista e revolucionária consistia em, do ponto de vista acadêmico, reiterar a postulação da validade da referência teórica marxista como instrumento eficaz tanto para a compreensão quanto para a transformação da realidade. Ora, nas condições em que o colapso das experiências de transição socialista era apontado pelos adversários do marxismo nos terrenos da política e da batalha das ideias como a pretensa comprovação 
de sua nulidade, me senti motivado a buscar na própria reflexão marxista uma interpretação objetiva daqueles processos.

Essa motivação me levou a elaborar um projeto de pesquisa sobre o processo de crise e colapso das experiências de transição socialista na Europa Centro-Oriental através do estudo de uma corrente de pensadores marxistas alternativos à institucionalidade político-intelectual do sorex, conhecidos como "marxistas críticos do Leste Europeu". Integravam esta vertente autores de diferentes sociedades euroorientais como os intelectuais húngaros do "Círculo de Budapeste" (Agnes Heller, Ferenc Ferrer, Gyorgy Markus, Andras Hegedüs), dissidentes tchecos participantes ou influenciadores da "Primavera de Praga" (Karel Kosic, Jri Pelikan, Zdenek Mlynar), neocomunistas alemães-orientais (Rudolf Bahro, Robert Haveman), intelectuais de esquerda polacos de diferentes extrações (Leszek Kolakovsky, Adam Schaff, Kuron \& Modzelewsky).

Uma primeira versão deste projeto foi aprovada tanto na seleção do doutorado do IUPERJ, em fins de 1993, quanto na USP, em abril do ano seguinte. Porém, decidi abandoná-lo em face de alguns obstáculos: a) apesar de aprovado, não havia, no IUPERJ, quem o orientasse; b) meu pouco (alemão e russo), em alguns casos nenhum (húngaro, por exemplo), conhecimento dos idiomas de boa parte dos autores selecionados inviabilizava a leitura, no original, de obras essenciais; c) a maior parte das instituições acadêmicas dos países do leste não tinha boa receptividade a estágio de pesquisadores estrangeiros; d) dúvidas e questionamentos sobre a caracterização de alguns pensadores escolhidos como marxistas, quando do colapso dos regimes (casos, em especial, de Heller, Kolakowsky, Pelikan, Kuron e Modzelewsky). Observo, en passant, que publiquei dois trabalhos no período 1995-1996, onde expresso meu interesse nos processos de ascensão e queda das experiências de transição socialista no Leste Europeu. Foram "Crisis, transicción y libre mercado" 2 e o capítulo de livro: "Europa do Leste: da resistência antifascista às democracias populares"3.

Por outro lado, minha filiação à tradição marxista, o mestrado em Relações Internacionais e minha experiência docente nesta área do conhecimento me frenteavam algumas questões: a) o instrumental teórico marxista pode ser utilizado para o estudo das relações internacionais? b) existe uma teoria marxista das relações internacionais? c) existiu uma reflexão marxiana-engelsiana das relações internacionais?

Como afirmei antes, os últimos anos da década de 1980 e os primeiros do decênio seguinte foram marcados pelo colapso do sorex, a ascensão do neoconservadorismo e do neoliberalismo e a proclamação de sucessivos necrológios da tradição marxista. Inconformado com esta situação, à medida que reconsiderava as possibilidades de levar adiante a pesquisa sobre o marxismo crítico do Leste Europeu, me sentia crescentemente motivado pela ideia de realizar uma pesquisa que, desafiando o Zeitgeist hegemônico no universo acadêmico das relações internacionais, recuperasse a contribuição do marxismo clássico a esta área de estudos e argumentasse em prol de sua vigência também neste território acadêmico, político e intelectual tão adverso. A concretização deste objetivo implicava duas realizações sucessivas: a) confrontar o veredito de luminares do pensamento político e das relações internacionais, como Raymond Aron, Noberto Bobbio, Claus Kernig, Kubalková \& Cruishank, sobre a impossibilidade de usar a referência teórica marxista no estudo das relações internacionais; b) demonstrar a existência de um corpus documental, 
composto por escritos dos demiurgos da filosofia da práxis, dedicado às questões internacionais do seu tempo, do qual fosse possível extrair elementos teórico-analíticos válidos não apenas para a época em que foram produzidos, mas também potencialmente inspiradores em nossos dias.

Resumidamente, as formulações que exigiam desafio eram as seguintes: tanto Aron quanto Bobbio negavam a possibilidade de uma teorização marxista das relações internacionais de caráter satisfatório já que, segundo eles, não havia, nas obras dos fundadores da tradição nem nas de seus sucessores, dois elementos basilares para a existência de uma verdadeira teoria das relações internacionais, a saber, uma teorização sobre o Estado enquanto ente autônomo face às determinações da economia e das lutas de classes e uma teoria da guerra igualmente autônoma e distinta de uma teoria da revolução. C. D. Kernig, por sua vez, sentenciava que a obra de Marx e Engels não continha teoria própria das relações internacionais, apenas uma teoria derivada. Também neste caso, derivada das interpretações marxianas e engelsianas acerca dos processos de reprodução ampliada do capital, da luta de classes e da revolução. Kubalkova \& Kruishank, que se dedicaram a buscar, na obra dos pensadores revolucionários alemães, os fundamentos da política exterior dos países da transição socialista, por sua vez afirmavam: "A principal dificuldade que cerca o estudo das idéias de Marx sobre as relações internacionais parece se dever ao fato de que ele dedicou muito pouca atenção explicita ao tema"4.

Para minha fortuna, havia outros autores, como Salomon Bloom, Kostas Papaioannou e Miklós Molnár que, divergindo dessas formulações negacionistas, sinalizavam a existência de uma persistente preocupação com as questões da realidade internacional no pensamento dos fundadores da tradição marxista, mencionando inclusive a atividade jornalística dos revolucionários alemães na imprensa europeia e norte-americana do século XIX como registros de tais preocupações e elaborações. No rastro desta pista, alterei meu objeto de pesquisa no primeiro semestre de 1995 combinando alguma intuição com as indicações acima mencionadas. Nos anos de 1997 e 1998 estive na Europa, recolhendo, sobretudo no Reino Unido, fontes primárias para o desenvolvimento de análises sobre as elaborações de Marx e Engels a respeito dos assuntos internacionais das décadas de 50 e 60 do século XIX. Buscava os escritos de Marx e Engels nas páginas do diário estadunidense New York Daily Tribune. O resultado foi uma tese de doutorado com o quilométrico e barroco título Mercados, diplomacia e conflito: uma abordagem histórica das relações internacionais no século XIX, através dos artigos publicados por Karl Marx e Friedrich Engels no the New York Daily Tribune, defendida e aprovada em 18 de novembro de 1999.

\section{Germinal: Em 2020 celebramos os 200 anos do nascimento de Friedrich Engels. Você pode apresentar às leitoras e aos leitores da Germinal nosso festejado?}

Engels nasceu em 1820 em Barmen, na província do Reno do reino prussiano. Seu pai era fabricante. Em 1838, sem se formar no ensino médio, foi forçado por circunstâncias familiares a entrar para os escriturários de uma casa de comércio de Bremen. Já em março de 1839, o jovem Engels, então com 19 anos, publicava no Telegraph für Deutschland de Hamburgo suas “Cartas de Wuppertal”). Nos sete anos seguintes, anteriores às publicações conjuntas com Marx nos jornais alemães, Engels publicou 
aproximadamente 25 artigos em diversos órgãos como o Anuário Alemão para a Ciência e a Arte de Leipzig, O Republicano Suíço, o Anuário Renano para a Reforma Social no periódico britânico The Northern Star e na própria Gazeta Renana. Seus textos versavam sobre uma ampla gama de temas ligados à realidade política, econômica e social dos estados alemães e da Inglaterra (onde passaria a residir a partir de 1842), como pode ser evidenciado em artigos como: "O socialismo no continente", "História da legislação inglesa sobre os cereais" e "A propósito dos bancos prussianos" e, acima de tudo, o ensaio que impressionou profundamente Marx e descortinou o horizonte da futura amizade pessoal e colaboração político-intelectual entre ambos, o "Esboço de uma crítica da economia política", publicado em 1844 nos

\section{Anais Franco-Alemães}

Mudou-se para Manchester, então o principal centro da indústria britânica, em 1842, ingressando em uma firma industrial, da qual seu pai era um dos principais acionistas. Ali, Engels não apenas se sentou em um escritório de fábrica, ele caminhou pelos bairros sujos onde se amontoavam os trabalhadores, viu aquela pobreza e miséria com seus próprios olhos. Mas ele não se contentou com observações pessoais, leu tudo o que encontrou sobre a posição da classe trabalhadora inglesa e estudou cuidadosamente os documentos oficiais de que dispunha. O fruto desses estudos e observações foi um livro publicado em 1845 :

\section{A Situação da Classe Trabalhadora na Inglaterra.}

Sua produção conjunta com Marx nas páginas da imprensa alemã teve início com a publicação de uma "Saudação dos comunistas democráticos alemães em Bruxelas ao Sr. Feargus O’Connor"), publicado no The Northern Star de 25 de julho de 1846. Porém, a fase mais prolífica desta atividade jornalística conjunta ocorreu no biênio 1848-1849, época que Marx exerceu a editoria da Nova Gazeta Renana) e teve em Engels um dos mais assíduos colaboradores do diário. Neste período, saíram de suas lavras 196 artigos, 110 sob a firma de Marx e 86 sob a de Engels. Por ser um porta-voz dos setores democráticos e republicanos da sociedade alemã de então, a NRZ não só acompanhava estreitamente o desenvolvimento daquele processo, como também tomava partido ao lado das forças de esquerda em ação naquela conjuntura, estigmatizando e fustigando ao máximo os setores mais conservadores e/ou contrarrevolucionários. Tal engajamento lançaria, pela primeira vez, os dois amigos no centro dos conflitos políticos de seu tempo, selando uma cooperação revolucionária que se estenderia por quase quatro décadas.

Entre o final de 1847 e o início de 1848, por solicitação da Liga dos Comunistas, antiga Liga dos Justos, organização de exilados alemães em Londres, Engels redigiu o esboço do que viria a ser o Manifesto do Partido Comunista. As anotações, apresentadas sob o título de Princípios do Comunismo, receberia de Marx sua elaboração definitiva em fevereiro de 1848.

Os acontecimentos revolucionários de 1848 trouxeram para o centro das preocupações de Marx e Engels a dinâmica dos assuntos internacionais por dois motivos: primeiro, em consequência da abrangência europeia dos movimentos insurrecionais que, ao longo de quase todo o continente questionavam o status quo do Congresso de Viena e segundo, porque o tema da unificação alemã se apresentava como uma questão internacional não só por envolver os diversos estados alemães afetados pelo problema, mas também por interferir nas relações de poder do conjunto do continente e, mais dramaticamente, da região centro oriental da Europa. De fato, o movimento de superação da fragmentação 
nacional das populações germânicas erigia uma ampla gama de problemas como os que diziam respeito ao Estado que assumiria a hegemonia do processo, a questão das relações austro-prussianas e das nacionalidades não germânicas no interior do império austríaco, o problema nacional da Polônia e da Hungria, as relações dos estados alemães com os impérios austríaco e otomano, etc. Tratava-se, portanto, de um elenco de reflexões nas quais a dimensão internacional migrava da periferia de suas preocupações, centradas nos assuntos concernentes a uma possível revolução democrática europeia, para posições próximas ao núcleo do pensamento dos autores. A intensa atividade jornalística de Marx e Engels ao longo do decênio 1839-1849 representou não apenas o período de formação teórico-política daqueles que viriam a ser dois dos mais importantes líderes do movimento operário europeu nas décadas seguintes, mas significou também a fase de conformação de uma visão de mundo internacionalista, na qual a consciência da vinculação indissolúvel entre os componentes nacionais e internacionais da dinâmica política dos países europeus constituiria o fundamento para as análises internacionais elaboradas no período 1851-1862, época de sua colaboração com o diário norte-americano New York Daily Tribune.

Até 1870 Engels morou em Manchester e Marx em Londres, o que não lhes impediu a mais viva comunicação espiritual. Eles se correspondiam quase diariamente, trocavam opiniões e conhecimentos e trabalhavam juntos para desenvolver o socialismo científico. Em 1870, Engels mudou-se para Londres e até 1883, quando Marx morreu, esta parceria de trabalho árduo e profícuo continuou.

Com a morte de Marx antes de concluir aquela que seria a sua obra máxima, Engels assumiu a tarefa de organizar e editar os livros II e III de O Capital. Este trabalho foi tão importante e realizado com tanto esmero, que Lenin defendia que estes dois últimos livros fossem considerados de autoria conjunta entre Marx e Engels.

Finalmente, após o falecimento de Marx, Engels passou a ser considerado como a principal referência política e intelectual do movimento socialista europeu. Participou da fundação da Internacional Socialista, em 1889 e integrando as fileiras da socialdemocracia alemã, atuou, até a sua morte em 1895, como liderança teórica e política do movimento, procurando orientá-lo para que mantivesse a perspectiva revolucionária, combatendo os desvios reformistas e deterministas que se manifestavam no mesmo.

\section{Germinal: Como se explica a construção da memória da posição secundária de Engels em relação a Marx na formulação da teoria marxista? Qual é a sua avaliação a respeito dessa polêmica?}

O próprio Engels sempre se atribui uma posição secundária no processo de elaboração do marxismo clássico ou do materialismo histórico como ele costumava designar esta construção teóricopolítica. Em vários escritos redigidos após a morte de Marx (cartas, introduções, prefácios e até uma obra de peso como o Ludwig Feuerbach e o Fim da Filosofia Clássica Alemã, de 1886), ele apresenta Marx como um gênio inalcançável, um primus inter pares, o maior pensador de sua geração. O problema é que, já só século XX, alguns expoentes do chamado marxismo ocidental passaram a abordar a contribuição de Engels à construção do marxismo de maneira fortemente crítica e por vezes até pejorativa. O pensamento 
de Engels, particularmente sua produção realizada após o desaparecimento de Marx, passou a ser diretamente associada aos aspectos problemáticos das apropriações do marxismo que predominaram no âmbito da II Internacional. O fato de Kautsky e Bernstein (expoentes respectivamente do reformismo político e do revisionismo teórico que acabaram por prevalecer naquela organização) terem sido, em alguns momentos, correspondentes e integrantes do círculo de socialistas próximos a Engels era um dos argumentos apresentados em defesa de tal associação. Escritos engelsianos como o Anti-Dühring, Dialética da Natureza (uma obra que Engels jamais publicou) e A Origem da Família, da Propriedade Privada e do Estado, foram criticadas por conterem derrapagens de caráter deterministas e reducionistas e apontadas como uma das principais antecipações dos desvios esquemáticos e naturalistas do marxismo produzido na União Soviética a partir do período estaliniano.

Entendo que, como marxistas, devemos agir permanentemente com espírito crítico e autocrítico, tanto em relação à nossa própria atividade teórico-prática quanto com relação aos próprios fundadores de nossa tradição de pensamento. Porém, para não incorrermos em impugnações arbitrárias e anacrônicas, necessitamos contextualizar os fenômenos. Assim, no que diz respeito aos alegados "problemas" do marxismo de Engels, penso que devam ser levados em consideração os seguintes fatores:

a) Existiu, de fato, uma divisão intelectual do trabalho entre Marx e Engels, na qual coube a Marx, em geral, a produção de estudos e análises de maior densidade e profundidade e a Engels elaborar escritos que contribuíssem para difundir em um âmbito mais amplo suas concepções e posicionamentos teórico-políticos. Esta diferenciação - efetiva, embora não universal e nem absoluta (que se pense na vasta produção jornalística de Marx e nos escritos históricos e teóricos produzidos por Engels, ainda nos anos de vida de Marx) - se acentuou e consolidou no período em que Engels atuou como grande divulgador do marxismo junto ao movimento operário e socialista internacional, após a morte de Marx.

b) Não obstante as distinções mencionadas acima, Engels colaborou política, teórica e intelectualmente com Marx durante quatro décadas. Algumas das mais importantes obras da tradição marxista foram elaboradas conjuntamente. Sob a rubrica de Marx foram publicados dezenas de textos na verdade elaborados por Engels. Os livros II e III d’O Capital, atribuídos a Marx, foram, como já vimos, coligidos, organizados e finalizados por Engels. Por outro lado, um capítulo do tantas vezes criticado Anti-Dühring de Engels teria sido redigido pelo próprio Marx. Ora, até hoje, ao que me consta, jamais foi localizado um único texto de Marx, principalmente troca epistolar realizada com o próprio Engels ou qualquer outro correspondente, na qual se encontre qualquer reparo do Mouro às supostas deformações esquemáticas, reducionistas e deterministas de seu grande amigo e camarada. Teria sido Marx, extremamente agudo e rigoroso na constatação das limitações e equívocos dos maiores intelectuais de seu tempo, incapaz de detectá-los nos escritos de seu próprio parceiro?!

c) Engels viveu até 1895, testemunhou a ascensão de novas e velhas concepções: idealistas, evolucionistas, deterministas e positivistas, que conquistavam primazia crescente na vida intelectual europeia nas últimas décadas do século XIX, inclusive no interior do movimento 
socialista. Não se furtou ao combate direto ou indireto contra tais concepções, suas últimas obras e escritos são registros deste engajamento. Contra a naturalização das relações patriarcais, a sacralização da propriedade privada e do Estado, investigou suas origens históricas e sociais, sua condição de construções da atividade humana, que poderão e deverão ser historicamente superadas. Contra a persistente influência das concepções místico-religiosas sobre a vida social, dialogou com as ciências naturais e investigou a historicidade das crenças cristãs. Contra a crescente penetração de abordagens empiristas e antidialéticas na socialdemocracia alemã, recuperou a relevância da filosofia clássica alemã e de sua superação teórica no processo de afirmação do marxismo. Ele, obviamente fez tudo isto na condição de um pensador extraordinariamente dotado, porém sem aderência aos cânones universitários. Realizou um esforço quase ciclópico de assimilações das mais recentes conquistas da ciência de seu tempo, mas não o fez na condição de um especialista ou pesquisador em tempo integral dos aspectos da realidade sobre os quais se debruçou. Ademais, alguns destes escritos possuíam um nítido caráter polêmico, outros, como os reunidos na publicação póstuma Dialética da Natureza, sequer receberam um tratamento adequado a sua publicação. Por todos estes motivos, penso ser preciso encarar tais trabalhos engelsianos como a mais elevada contribuição de alguém que trabalhou nos limites das circunstâncias com as quais teve de lidar. Por mais datadas e, sob muitos aspectos, superadas que estas obras sejam consideradas hoje, é preciso inseri-las no contexto de seu tempo e motivações e recuperar, sobretudo, sua relevância na defesa imprescindível de uma abordagem, materialista, histórico-dialética e teórico-crítica dos fenômenos dos quais se ocupou.

Isso posto, entendo que todos os esforços para diminuir a importância de Engels na elaboração do marxismo clássico são inconsistentes e anacrônicos.

\section{Germinal: Quais são as decisivas contribuições e obras de Engels ao marxismo? De onde decorre a atualidade dessas contribuições?}

Como tem sido dito e repetido, Engels é cofundador do marxismo clássico. Participou diretamente da elaboração, juntamente com Marx, de grandes clássicos da tradição marxista, como A Ideologia Alemã, O Manifesto Comunista, A Sagrada Família, e foi o responsável, como já observado, pela publicação dos livros II e III d'O Capital. Além desta produção conjunta, Engels se aprofundou no estudo de temas que Marx não abordou sistematicamente, como a arte e a ciência da guerra, a história das insurreições camponesas na Alemanha, as origens da família patriarcal, da propriedade e do Estado e os primórdios do cristianismo. Foi também Engels quem despertou o interesse de Marx pela economia política, sendo, aparentemente, quem o conduziu a atividade política prática.

Penso que a atividade política e intelectual de Engels ainda hoje pode nos inspirar sobre vários aspectos. Em primeiro lugar no que se refere à articulação orgânica, consciente e consistente entre teoria e prática. Engels foi um pensador combativo e militante, combateu em insurreições democráticas e 
republicanas e atuou nos movimentos socialista e operário. Jamais se fechou em gabinetes. Não foi um "socialista de cátedra" ou um revolucionário de papel. Foi, juntamente com Marx e, em certos aspectos, de forma mais abrangente que este, uma personificação real da noção de práxis. Em segundo lugar, Engels foi um pensador materialista e dialético como muito poucos na história, pioneiro na aplicação do método de investigação que desenvolveu ao lado de Marx à abordagem de uma gama extremamente variada de fenômenos, processos e aspectos da realidade. Em terceiro lugar, Engels foi, não obstante a persistente atualidade de muitas de suas reflexões e posicionamentos, um homem de seu próprio tempo. Vinculou-se à mobilização e lutas das forças políticas e sociais mais avançadas da segunda metade do século XIX, O radicalismo republicano e democrático e o movimento socialista e operário. Manteve-se a par das realizações mais inovadoras das ciências, tanto humanas quanto naturais, da técnica e da filosofia. Emulou, com sua produção intelectual, as personalidades mais importantes do pensamento e da ciência de sua época.

Seu espírito contestador, sua curiosidade intelectual, sua combatividade militante, a amplitude de suas perspectivas ainda nos fornecem exemplos valiosos de comportamento em um mundo marcado por tantas desigualdades, injustiças e retrocessos, políticos e sociais, econômicos e culturais.

\section{Germinal: Quais as batalhas teórico-práticas de Engels na sua militância política e intelectual? E qual sentido tem essas batalhas para nós, hoje?}

Engels tornou-se socialista apenas na Inglaterra. Em Manchester, ele se envolveu com os líderes do então movimento trabalhista britânico e começou a escrever para publicações socialistas inglesas. Em 1844, a caminho da Alemanha, encontrou Marx em Paris, com quem já havia iniciado uma correspondência. Marx, sob a influência dos socialistas franceses e da vida francesa, também se tornou um socialista. Já amigos, escreveram um livro juntos: A Sagrada Família ou Crítica da Crítica Crítica. Este livro, publicado um ano antes de A situação da Classe Trabalhadora na Inglaterra de Engels, foi escrito em sua maior parte por Marx e lançou as bases da colaboração política e intelectual que marcaria profundamente a história do socialismo revolucionário a partir de então.

De 1845 a 1847, Engels passou entre os trabalhadores alemães em Bruxelas e Paris combinando estudos científicos com atividades práticas. Redigem conjuntamente A Ideologia Alemã e estabelecem um relacionamento com a secreta Liga dos Comunistas, que os instruiu a esboçar os princípios básicos do socialismo que haviam desenvolvido. É assim que surgiu o já mencionado Manifesto do Partido Comunista de Marx e Engels, publicado em 1848.

Após o movimento de 1848-1849. No exílio, Marx e Engels estavam engajados em mais do que apenas ciência. Marx participou da criação da Associação Internacional de Trabalhadores (A.I.T.) em 1864, integrando seu Conselho Geral por quase uma década. Engels também participou ativamente de desta organização. As atividades desta Primeira Internacional, que unia, segundo Marx, os proletários de todos os países, foram de grande importância no desenvolvimento do movimento operário e mesmo após seu fechamento, na década de 1870, o papel unificador de Marx e Engels não terminou. Ao contrário, pode-se dizer que sua importância como líderes políticos e intelectuais do movimento operário crescia, porque o 
próprio movimento se expandia. Após a morte de Marx, Engels continuou como principal conselheiro e líder dos socialistas europeus. Ele foi igualmente abordado para aconselhamento e orientação pelos socialistas alemães, cuja força, apesar da perseguição do governo, aumentava rápida e continuamente e por representantes de países situados na periferia europeia do capitalismo de então - por exemplo, os espanhóis, romenos, russos -, obrigados a ponderar e avaliar seus primeiros passos. Todos eles se basearam no rico tesouro de conhecimento e experiência do velho Engels.

Germinal: Professor Muniz, em 2007, você lançou pela editora da UFBA, junto com Mauro Castello Branco de Moura e José Ricardo Moreno Pinho, uma coletânea intitulada Friedrich Engels e a ciência contemporânea. Como você avalia as contribuições de Engels, em seu tempo, a esse tema da ciência, e sua atualidade face ao avanço do ceticismo e do negacionismo científico?

Como já foi dito, Engels, assim como Marx, pertenceu à vanguarda política e intelectual de seu tempo. Nesta condição não apenas participou e coliderou alguns dos principais movimentos políticos e sociais da segunda metade do século XIX, o movimento republicano-democrático e o movimento operário socialista, mas também acompanhou, interagiu e até concorreu para o avanço da ciência e do conhecimento naqueles dias. Para além de sua reconhecida contribuição ao desenvolvimento das então chamadas "ciências do espírito" (Geisteswissenchaften), Engels também enriqueceu o conhecimento pré-existente nos âmbitos da arte e ciência da guerra, bem como no domínio das ciências naturais.

Seu valioso aporte ao estudo das questões militares tem sido, ainda que tardiamente, reconhecido e revalorizado. Já seu esforço intelectual no sentido de aplicar a perspectiva dialética ao campo das ciências da natureza (Natürwissenchaften), vem sendo objeto de intensa controvérsia. Resgatado por cientistas dialéticos como JBS Haldane, Joseph Needham Paul Langevin e A.I. Oparin, é, por outro lado, rechaçado por outros cientistas, sobretudo de filiação empirista e neopositivista.

A coletânea que publicamos em 2007 foi o registro parcial das intervenções realizadas em um seminário organizado na UFBA, no ano de 2005, em homenagem a Friedrich Engels por ocasião do $110^{\circ}$ aniversário de sua morte. Movia-nos o interesse de resgatar a contribuição engelsiana à construção do pensamento científico como contraponto às abordagens idealistas, irracionalistas e metafísicas em ascensão na vida cultural e mesmo nos espaços acadêmicos. Considero que a ofensiva desenfreada de discursos e concepções abertamente obscurantistas e de negação da ciência em curso na atualidade confirmam a validade daquela iniciativa.

Germinal: Marx e Engels escreveram milhares de páginas em textos jornalísticos, muitos deles contendo análises sobre a política internacional na segunda metade do século XIX. Qual é o peso de tais textos na obra dos dois revolucionários alemães? E quais são as contribuições dos pais do marxismo, aos estudos sobre relações internacionais hoje em dia? 
Os primeiros artigos que Marx e Engels dedicaram às relações diplomáticas entre os estados europeus no Tribune tiveram, como pano de fundo, o refluxo dos movimentos revolucionários disseminados ao longo do continente no período 1847-1849 e o estabelecimento do Segundo Império Francês sob a direção de Luiz Bonaparte no ano de 1851. Foi justamente à atividade deste último personagem, que os dois articulistas dirigiram suas primeiras observações em matéria de diplomacia internacional. Contudo, no primeiro ano de colaboração de Marx e Engels para com o Tribune, a emergência nacional das populações da Europa Centro-Oriental e o balanço dos movimentos democráticoradicais no interior do mundo germânico constituíram os temas privilegiados da correspondência jornalística dos dois pensadores revolucionários alemães com o diário estadunidense.

Somente a partir do biênio 1853-1854, as articulações político-diplomáticas entre os principais estados nacionais europeus situaram-se no centro das preocupações internacionais dos dois companheiros de lutas e letras. Os interesses internacionais tangidos pelo movimento de unificação italiana, o destino da Turquia e as ações da Rússia foram os temas internacionais que mais catalisaram a atenção de Marx e Engels neste período.

Não lhes escapou ao olhar os propósitos restauracionistas e conservadores que presidiram a fundação do sistema internacional da Convenção de Viena, dirigidos à construção de um sistema de segurança coletiva que preservasse os regimes monárquicos e absolutistas europeus da ameaça revolucionária. Interessados como estavam nos destinos do movimento revolucionário na Europa, Marx e Engels não pouparam críticas às concepções e aos métodos das cinco potências (Áustria, Prússia, Rússia, Inglaterra e França) constituintes do núcleo duro deste sistema. Para eles, por trás da verborragia altissonante dos homens de estado europeus do período ocultavam-se objetivos inconfessáveis: o desejo de supremacia e o repúdio à revolução e tais desígnios não poderiam inspirar senão ações internacionais caracterizadas pelo desrespeito à soberania nacional e a prática sistemática de chantagens e intimidações no tratamento dispensado aos estados menores. Como regra geral, vigorava, portanto, a prática da interferência recíproca nos assuntos internos de outros estados, limitada apenas pelo equilíbrio de poder nas relações entre eles.

Ainda naquele contexto, Marx e Engels já percebiam o aprofundamento das tensões entre as potências europeias com relação aos problemas do Oriente Próximo. Verificava-se um deslocamento da atenção dos principais estados euro-ocidentais para as perspectivas geradas pela deterioração do poder do Império Turco. O que significava possibilidades reais de absorção de parcelas valiosas do antigo império dos sultões como aquelas situadas na região dos Balcãs ou nas imediações do Estreito de Bósforo e dos Dardanelos. Desta forma, uma extensa série de artigos dos dois autores versou sobre a chamada "Questão Oriental", ponto nodal da futura Guerra da Criméia.

Pensadores dialéticos, Engels e Marx compreendiam as implicações que o movimento particular dos estados impulsionados por "interesses nacionais" não expressamente vinculados às necessidades do capital e às aspirações econômicas das classes dirigentes europeias poderia produzir para o desenvolvimento histórico revolucionário do continente. Ademais, vivendo no contexto político-cultural anglo-saxônico e tendo como interlocutoras privilegiadas as opiniões públicas inglesa e norte-americana, os dois autores não poderiam deixar de moldar suas análises internacionais segundo temas e, sob certo aspecto, valores 
característicos das tradições anglo-americanas em matéria de política e diplomacia internacionais. Isto, porém, não significa que a compreensão dos fenômenos internacionais em termos de uma "política de poder" protagonizada pelos estados nacionais — e não pelas classes sociais — impulsionados por seus interesses "estratégicos" desenvolvida pelos colaboradores europeus do Tribune tenha significado apenas uma adequação oportunista aos padrões de análise dominantes. A especificidade da visão de Marx e Engels consiste justamente em sua capacidade singular de articular estas duas dimensões distintas, porém interligadas e situadas na base do desenvolvimento das relações internacionais de seu tempo: a esfera dos interesses sociais conflitantes, motor da luta de classes e catalisador de possíveis revoluções político-sociais no interior dos estados e no marco europeu e a esfera da ação dos estados nacionais, determinada por interesses estratégicos de poder e geradora das configurações dos sistemas internacionais.

Ainda serve de modelo aos analistas contemporâneos das relações internacionais a capacidade de Marx e Engels de conceituar adequadamente a essência dos fatores determinantes dos processos da política mundial em cada situação específica. Avessos a qualquer reducionismo, foram capazes de identificar a vigência das determinações geoestratégicas em determinados cenários, a preponderância dos objetivos econômicos em outros contextos e até a dinâmica cultural por detrás de certos conflitos. Acima de tudo, interpretaram as ações dos estados na cena internacional como resultado de interações complexas no seio das sociedades nacionais no curso das quais o processo de decisões sobre a política externa poderia assumir maior ou menor autonomia em relação aos próprios interesses e objetivos das classes hegemônicas no âmbito nacional de cada sociedade em particular.

Germinal: Em 2020, você e Felipe Vale da Silva organizaram uma coletânea de textos de Marx e Engels sobre a Guerra Civil estadunidense, que foi lançada pelas editoras Aetia e Peleja. Quais são as ideias centrais contidas nos artigos de Marx e Engels sobre o tema? Além disso, você poderia nos falar como estes textos relacionam classe, raça e revolução?

Uma das principais intenções de Marx e Engels ao redigirem seus artigos sobre a Guerra Civil estadunidense nos veículos da imprensa europeia foi informar a opinião pública sobre suas verdadeiras motivações. Polemizaram abertamente com a abordagem de alguns órgãos noticiosos, que escamoteavam a confrontação entre o projeto de expansão do escravismo dos secessionistas e a plataforma abolicionista dos partidários da União, atribuindo a questões tarifárias e à disputa entre nortistas e sulistas pelo controle do governo dos Estados Unidos como as causas da guerra. Para Marx, o conflito entre o Norte industrial e burguês e o Sul oligárquico e escravista era não apenas inevitável, mas também a força motriz da história estadunidense durante meio século.

Ao analisar o conteúdo das duas distintas formações que coexistiam no mesmo território nacional, Marx constatou que a baixa produtividade relativa da produção escravista do Sul - vis-à-vis com a concorrente industrial do Norte - exigia, para se tornar remunerativa, a exploração de amplos contingentes de escravos e a incorporação sistemática de novas extensões de solo fértil, conferindo à escravidão sulista um caráter tendencialmente expansionista. Para que aquela classe formada por uma minoria de grandes proprietários 
fundiários mantivesse sua dominação sobre uma maioria de brancos pobres, destituídos de terra, uma condição era imprescindível: a corrupção ideológica dos despossuídos pelos oligarcas escravistas, que lhes acenavam a possibilidade de, a partir da obtenção de novos territórios, virem a se transformar, também eles, em senhores de escravos.

Por outro lado, observava Marx, a coisificação e a impiedosa exploração dos trabalhadores escravizados pelos latifundiários do Sul estabeleciam uma base objetiva para a intensificação da exploração da força de trabalho dos operários assalariados do Norte e uma ameaça ao reconhecimento de quaisquer de seus direitos constitucionais. Em outras palavras, para Marx e Engels, a existência da escravidão nos estados do Sul não era uma excentricidade inofensiva e passível de coexistência, mas sim uma força expansionista e reacionária, exercendo uma influência nociva e corruptora sobre o conjunto da formação social estadunidense.

Portanto, a categórica condenação de Marx e Engels ao regime escravista não se devia apenas a considerações de caráter econômico, político e humanitário. Na perspectiva que compartilhavam acerca das possibilidades do processo revolucionário internacional, Marx e Engels entendiam a Guerra Civil como um desdobramento histórico da Revolução Americana dos anos 1776-1783. Viam, no apoio do operariado europeu à causa abolicionista nos EUA, um momento importante na elevação do nível de sua consciência política, não apenas do ponto de vista do internacionalismo, mas, sobretudo, no fortalecimento da luta contra o capital em escala mundial. Eles também consideravam o triunfo das forças abolicionistas, e consequente emancipação dos escravos, um prelúdio da elevação do nível das lutas da classe operária europeia.

Essa compreensão é realçada no artigo "Uma união operária em Londres", no qual Marx, ao comentar a realização de um comício operário organizado para se opor à intervenção inglesa na Guerra Civil norte-americana (que ocorreria, inquestionavelmente, em favor do Sul e contra o Norte), destacava o elevado discernimento dos trabalhadores ingleses ao hipotecar o seu apoio à causa da União e à luta abolicionista, não obstante as terríveis privações que viviam em consequência da diminuição do comércio de algodão com os estados do Sul. Inversamente, criticava a estreiteza de interesses das classes dominantes inglesas ao atribuírem as dificuldades econômicas e sociais experimentadas pelo povo e trabalhadores à adoção de medidas protecionistas pelos estados do Norte dos EUA e ao bloqueio econômico praticado por eles contra os estados do Sul.

Desmentindo afirmações infundadas e críticas mal intencionadas, tais escritos apresentam um posicionamento claramente antiescravista, antioligárquico, abolicionista e favorável à emancipação dos trabalhadores e dos povos, perfilando-os ao lado das forças políticas, sociais e intelectuais mais avançadas do século XIX.

Mais que isto, suas atitudes não se limitaram a hipotecar um apoio abstrato e remoto, eles se engajaram como articulistas de um jornal republicano-abolicionista e em folhas progressistas europeias, corroborando a causa da emancipação dos escravos através do apoio às forças do Norte e da oposição aos arranjos dissimulados e à possibilidade de intervenção inglesa em favor do Sul escravista. Por fim, observamos que Engels e Marx, na condição de teóricos e militantes da primeira organização operária internacionalista da 
história, preconizaram em seus escritos e buscaram realizar em suas ações uma unidade essencial entre a luta emancipadora dos trabalhadores escravizados deste lado do Atlântico e a luta pelo fim da exploração capitalista dos operários europeus.

\section{Germinal: Engels, assim como Marx, aliou a militância e a produção intelectual. Como você vê o papel do intelectual no momento atual e as relaçôes entre o intelectual e a militância política? Você já se deparou com algumas tensões como um intelectual no partido e como um militante na universidade?}

Penso que todo e qualquer intelectual realmente consciente não pode se eximir de tomar posição em face dos problemas de seu tempo. Particularmente nos dias de hoje, em que nos deparamos com uma crise omnímoda, manifestada em praticamente todos os aspectos da vida econômica, política, social e cultural, nada me parece mais condenável do que uma postura de indiferença ou omissão. Nem é preciso muito esforço para constatar que a gravidade dos dilemas civilizatórios e humanos que nos afetam tem suas raízes na supremacia inquestionável da dominação do grande capital e de seu processo de reprodução ampliada sobre todos os aspectos da sociabilidade humana. A tragédia ambiental que nos aflige, o cenário de pandemia, a ocorrência intermitente de conflitos, intervenções e guerras localizadas e a ameaça latente de uma confrontação militar de grandes proporções, a catástrofe econômica em boa parte do planeta, a ascensão de forças políticas e sociais ultrarreacionárias são fenômenos que não podem passar despercebidos para quem se dedica ao pensamento e a reflexão. Logicamente, a quase inesgotável variedade de sistemas de ideias e concepções existentes combinada com a divisão das sociedades em classes, a vigência e o acirramento das lutas de classes permite que os problemas mencionados sejam abordados de maneiras muito distintas. É óbvio que, neste terreno da formulação e confronto de ideias, os interesses sociais e as lutas de classes encontram forma de se expressar e manifestar nas interpretações e alternativas propostas para o enfrentamento desta crise multifacetada. Arriscando-me a incorrer em certo esquematismo, creio ser possível conectar, com todas as múltiplas mediações existentes, os interesses da grande burguesia e do grande capital às concepções ultraliberais e neoliberais na economia, tradicionalistas, obscurantistas e irracionalistas na filosofia e na análise social, conservadoras, neoconservadoras, autocráticas e fascistizantes na política. A nós, intelectuais conscientes, integrantes das classes trabalhadoras e dos setores da sociedade que sofrem intensamente com as opressões (mulheres, negros, LGBTs, populações periféricas, etc.), não nos cabe outra atitude que não passe pela análise crítica radical da realidade da ordem burguesa e do capitalismo contemporâneo e a tomada de posição ao lado das lutas dos trabalhadores e dos setores populares pela transformação das estruturas sociais. Por pensar desta forma, entendo que meu engajamento político e social não é, e nunca foi, um capricho ou uma veleidade, mas sim uma necessidade incontornável. Grandes obstáculos, porém, se apresentam diante de quem, na universidade, assume este tipo de posicionamento. As origens elitistas da universidade brasileira, criada originalmente para legitimar a reprodução dos privilégios sociais, bem como toda a tradição autocrática e excludente inscrita em nossa história conspiraram no passado, e ainda conspiram no presente, para que a universidade não esteja a serviço da resolução das 
grandes questões nacionais e do enfrentamento das profundas desigualdades existentes na sociedade brasileira. Desta forma, a militância no âmbito acadêmico e o engajamento político e intelectual em prol das lutas dos trabalhadores e setores populares são muito frequentemente encarados com estranhamento, quando não com hostilidade, nestes ambientes. Prevalece em amplos domínios da vida universitária a noção elitista, segundo a qual existe uma incompatibilidade entre a excelência acadêmica e a atividade política e socialmente engajada.

No que me diz respeito, a especificidade das Ciências Humanas, à qual me integro, e a legitimidade intelectual e institucional dos objetos a cuja investigação me dedico (Relações Internacionais, História do Tempo Presente, História Política e História Social) me oferecem possibilidades de conectar reflexões políticas e sociais com atuação como pesquisador e docente.

No que diz respeito à minha vinculação ao PCB, desde o início de minha militância, no começo dos anos 1980, e por todo o tempo de atuação em suas fileiras até os dias de hoje, o partido me proporciona estímulo permanente ao estudo e aprofundamento de minha compreensão da realidade. Do esforço de assimilação das bases teóricas e conceituais de suas elaborações política até o incentivo ao entendimento dos movimentos da conjuntura brasileira e internacional, sempre tive em minha militância partidária uma provocação permanente à elevação de meu nível cultural e intelectual. Por outro lado, apesar de ter origem proletária, ingressei no partido como militante secundarista, mais tarde me engajei no movimento estudantil e, há tempos, sou militante do partido na universidade. Logo, minha condição de intelectual primeiro em formação, mais tarde no pleno exercício da atividade profissional, sempre caracterizaram minha relação com o Partido Comunista Brasileiro. Portanto, devo dizer que jamais me senti constrangido, pressionado, ou estigmatizado por ser um intelectual, no interior do partidão.

\section{Germinal: Você poderia falar, comentar sobre as suas investigações sobre a política do PCB em relação ao movimento negro? Parece haver uma forte tendência, entre os movimentos negros atuais, ao esquecimento da importância da política dos comunistas nesta frente e também dos militantes negros do PCB.}

Ao longo da história e, particularmente, nas últimas décadas, vem ocorrendo um desentendimento crescente entre uma série de pessoas, correntes e mesmo organizações, que se colocam na linha de frente das lutas contra as opressões -, sobretudo, no nosso caso aqui, contra a opressão racial - sobre a compreensão do papel que o marxismo pode ou não desempenhar no apoio ao desenvolvimento destas lutas. Algumas destas correntes e concepções impugnam a possibilidade de que o marxismo e os marxistas participem ou ofereçam contribuições para estas lutas, ou mesmo uma alternativa aos dilemas mais profundos, com os quais o desenrolar dessas lutas se depara hoje em vários momentos e lugares.

Eu diria que estes desentendimentos são, em parte, a expressão legítima de um conhecimento limitado a respeito da obra de Marx e de Engels e seus já mencionados escritos contra a escravidão e o colonialismo. Há também, em largos setores dos movimentos de lutas contra as opressões, um patente 
desconhecimento do papel que, ao longo da história, os e as marxistas desempenharam nas lutas contra as opressões, o supremacismo e o racismo.

Para as classes dirigentes e os círculos supremacistas e racistas interessa que tais desentendimentos persistam e até se aprofundem de modo a impedir que as lutas antirracistas adquiram uma orientação radicalmente anticapitalista ao identificar na ordem burguesa e na dominação do capital os alicerces sócios históricos da vigência do racismo. Em outras palavras, corresponde aos interesses dos defensores do status quo político, econômico, social e racial existente, inviabilizar a convergência entre aqueles que acentuam a necessidade de combinar a luta contra as várias formas de opressão com a luta contra a exploração do capital sobre o trabalho. Neste sentido, certos posicionamentos afrocêntricos, diferencialistas e identitários, que adotam posicionamentos antimarxistas e anticomunistas, acabam, de forma consciente ou não, multiplicando, na prática, os obstáculos para que as lutas antirracistas foquem na necessidade de eliminar os fundamentos materiais objetos da reprodução do racismo em nossa sociedade: a hegemonia burguesa e as relações capitalistas.

Como resultado da influência das concepções afrocêntricas identitárias e diferencialistas que mencionei anteriormente, há em certos setores do movimento negro uma tendência a ignorar, diminuir e descaracterizar o papel que, ao longo da história, os comunistas brasileiros desempenharam na valorização da cultura afrobrasileira, na conquista e na defesa do povo negro e no desenvolvimento das lutas antirracistas. Para reverter esta situação, é imperativo recuperar uma história que acabou sendo invisibilizada.

Desde sua fundação, em março de 1922, o PCB se propôs a servir de instrumento para as lutas de emancipação do proletariado brasileiro. Este proletariado foi constituído, desde os seus primórdios, por uma massa significativa (quiçá majoritária) de trabalhadores e trabalhadoras afrobrasileiros. Relatos memorialísticos produzidos por dirigentes e militantes da primeira geração de comunistas brasileiros relatam que, desde seus primeiros dias, o partido teve em suas fileiras, e mesmo em seus órgãos de direção, quadros e militantes afrodescendentes. Basta uma rápida pesquisa nas páginas da imprensa comunista da primeira década de existência do PCB para localizar ali artigos de denúncia da discriminação racial contra a população negra e apelos aos trabalhadores e trabalhadoras negros e negras para que ingressassem no partido. Será que algum outro partido político brasileiro da década de 1920 adotava comportamento semelhante? Em uma época marcada pela adesão das elites brasileiras às ideologias eugenistas e em prol do embranquecimento da população?

Nas eleições presidenciais de 1930, o PCB, desafiadora e pioneiramente, apresentou o nome de Minervino de Oliveira, operário marmorista negro, como candidato a presidente. Em sua Primeira Conferência Nacional de julho de 1934, realizada na mesma época em que se iniciava a propagação da tese da "democracia racial brasileira", o partido denunciava o racismo das classes dominantes e se comprometia a apoiar todas as lutas pela igualdade de direitos econômicos, políticos e sociais de negros e índios. Ainda em meados da década de 30, o intelectual comunista baiano Edison Carneiro iniciou uma vasta e significativa obra de investigação e resgate da cultura afrobrasileira, tornando-se um dos pioneiros em tal campo de estudos e uma referência fundamental até os dias de hoje. Este mesmo Edison Carneiro, com o apoio de outros intelectuais comunistas como Jorge Amado e Aydano do Couto Ferraz, criou, em 1937, a União de 
Seitas Afro-Brasileiras, a primeira entidade criada no país com o objetivo de proteger e cultivar os valores e as tradições religiosas de matriz africana.

Na década de 1940, o PCB solidificou seu engajamento na luta contra o racismo e em defesa da cultura afrobrasileira. Sob sua legenda elegeu-se, em 1945, Claudino José da Silva, primeiro negro a exercer mandato parlamentar e primeiro constituinte negro da história do Brasil. Durante os trabalhos da Assembleia Nacional Constituinte de 1946, coube ao escritor e deputado comunista Jorge Amado a elaboração do projeto da primeira lei federal que estabeleceu a liberdade para a prática das religiões afrobrasileiras. Este período registra também a criação do Teatro Experimental do Negro, que tem como um de seus principais expoentes o ator, poeta e teatrólogo comunista Francisco Solano Trindade, quem marcou com sua atividade intensa a arte popular brasileira das décadas seguintes. Alguns anos mais tarde, apareceram os primeiros trabalhos de Clóvis Moura, então vinculado ao PCB, cuja produção aportou uma importante contribuição aos estudos históricos e sociológicos sobre o negro no Brasil.

Por outro lado, é verdade - e isto precisa ser reconhecido em caráter autocrítico - que, como parte de um processo de descaracterização e crise da identidade política dos comunistas, o PCB secundarizou a relevância da luta antirracista, subordinando-a às lutas mais gerais contra o imperialismo, a reação e o autoritarismo ditatorial-militar, principalmente nas décadas de 1970, 1980 e 1990. Como resultado, retardou, relativamente a outras organizações do movimento negro, a mobilização massiva de sua militância para a participação na luta contra o racismo e a discriminação racial no Brasil.

Nos últimos anos, no entanto, o partido vem estruturando nacionalmente o Coletivo Negro Minervino de Oliveira, através do qual procura mobilizar seus militantes para a participação no enfrentamento ao racismo estrutural vigente em nossa sociedade. Os militantes do Minervino reconhecem, apoiam e procuram participar das lutas de resistência e do encaminhamento das reivindicações de caráter imediato, parcial, conjuntural e/ou local da população afrodescendente. Isto inclui aqueles concernentes ao resgate e preservação da história e da cultura afrobrasileiras, incluindo a aplicação efetiva da Lei 10.639/2003, a reserva de vagas para estudantes e trabalhadores afrobrasileiros nas universidades e no serviço público, a titulação das terras e proteção às comunidades remanescentes de quilombos, o respeito ás religiões de matriz africana e a denúncia do extermínio da juventude negra como consequência de políticas de "segurança pública" de caráter proibicionista, repressivo, punitivo e definitivamente racista. O norte fundamental de atuação, no entanto, é a compreensão da necessidade insubstituível de entrelaçar a luta antirracista à luta anticapitalista.

\section{Germinal: Professor Muniz, Germinal agradece muito a sua entrevista. Você destacaria ainda algum apontamento sobre Engels?}

Parabenizo a revista Germinal pela iniciativa oportuna e necessária de homenagear Friedrich Engels por ocasião dos duzentos anos de seu nascimento. Considerando os tempos sombrios que estamos vivendo no Brasil e no mundo, é particularmente importante resgatarmos, como forma de alento e inspiração para as lutas que temos e teremos pela frente, uma oportuna caracterização de Engels acerca de 
nossa época, segundo a qual ainda nos encontramos na pré-história da humanidade. A verdadeira história humana somente se iniciará após o término das lutas de classes. Logo, o futuro da espécie humana está sendo decidido em nossos dias e dependerá dos resultados que poderão ou não ser alcançados nos embates pela emancipação humana.

\section{Notas}

1 Instituto de Ciências Humanas e Sociais. Universidade Federal Rural do Rio de Janeiro. graduação em Licenciatura em História pela Universidade Federal Fluminense (1987), mestrado em Relações Internacionais pela Pontifícia Universidade Católica do Rio de Janeiro (1992) e doutorado em História Econômica pela Universidade de São Paulo (1999). Lattes: http://lattes.cnpq.br/3218494978727386 Email: ferreiramuniz8@gmail.com

2 FERREIRA, M. G. Crisis, Transición y Libre Mercado. América Latina e Europa Centro Oriental Perspectivas Para o Terceiro Milênio, v.01, p.161-171, 1996.

${ }^{3}$ FERREIRA, M. G. Europa do Leste: da resistência antifascista às democracias populares. In: Segunda Guerra Mundial. Um balaço histórico. 1 ed. São Paulo/SP: Xamã, 1995, v.01, p. 357-383.

${ }^{4}$ V. Kubálková e A. A. Cruishank. Marxism-Leninism and theory of international relations. Londres, Routledge \& Kegan, 1980 e Marxism and International Relations. Oxford-New York, Oxford University Press, 1989.

Recebido em: 01.2021

Aceito em: 01.2021 